\begin{abstract}
S
Stefan Fröhlich

Foreign Policy under Obama - pragmatic multilateralism and transatlantic convergence
\end{abstract}

Politicians and media alike have assessed Barack Obama's victory in the 2008 US-presidential election to be 'historic'. In this article, the author considers how the policy agenda of the new US-administration might look like and what this could mean for the European Union. He also investigates whether Obama's pragmatic multilateralism will provide new possibilities for transatlantic convergence.

\title{
Daniela Schwarzer
}

Ten years governance of the Eurozone: economic effects and institutional dynamics beyond treaty revisions

During the first ten years of the European Monetary Union, economic developments and the experience with its still developing institutional architecture have led to explicit reforms and subtle adjustments of the mechanisms for coordinating economic policy within the Monetary Union. In the context of the financial and economic crisis new dynamics arise, which have already intensified the debate on governance. Although some of the arguments in this debate had already been prevalent during the negotiations on the Maastricht Treaty, some of the assumptions about mechanisms and processes of coordination in the Monetary Union have changed in several aspects since the introduction of the Euro. In the next few years, more institutional dynamics can be expected.

Hans-Wolfgang Platzer

Constitutional minimalism: European Social Policy in the treaty reforms from Nice to Lisbon

The article analyses the development and results of the treaty reforms concerning European social policy from Nice to Lisbon. Based on an overview of the development of the treaty base and the substantial results of European governance in the field of labour and social policy the author concludes that while the Lisbon Treaty specifies and enhances the normative importance of social policy, the allocation of competencies and the decision-making rules remain substantially the same. This finding of a constitutional minimalism leads to the following questions: Does the enlarged European Union suffer from a 'levels-of-competencies trap' and if yes, why? Which solutions and alternatives might determine future European social policy with regard to the emerging limits for a European social union?

Severin Fischer

Energy and Climate Policy in the Lisbon Treaty: additional legitimacy to react on growing challenges

While the European Council in March 2007 has formulated ambitious goals for European energy and climate policy, the Union's treaty base for this policy is still weak. The Lisbon Treaty establishes a new energy title, creating for the first time a specific treaty base for energy and climate policy. This might be of increasing importance in the coming years. The author describes the substance of the aspired treaty reforms and highlights possible impacts 
on the Union's legitimacy and its self-perception as a global actor. He concludes that while the ratification of the Lisbon Treaty might generate a positive dynamic for the integration of energy and climate policy, some fundamental principles still remain in the primary law that guarantee national governments to remain dominant actors within this policy.

\section{Jörg Semmler}

\section{The instrument of multi-annual programmes in European Justice and Home Affairs}

The cycle of the Hague Programme (2005-2009), the EU's five-year policy agenda for justice and home affairs, is coming to an end. Thus, the European Commission is currently working on a proposal for a subsequent multi-annual programme in this area. The programme has then to be passed by the European Council, probably in 2009. But what exactly is the added value of such multi-annual programmes? Are they adequate means of policysteering? And how should they be designed to ensure coordinated and coherent policies? The author examines the previous multi-annual programmes in the area of justice and home affairs to answer such questions. He also shows how drafting, design, and purpose of those programmes have changed over the years.

\section{Hans-Georg Ehrhart}

\section{EUFOR Tchad/RCA: interim review and recommendations for a more effective conflict solution}

Until March 2009 the hitherto largest autonomous ESDP-mission (EUFOR Tchad/RCA) shall provide a safe and secure environment in Chad and the Central African Republic. With regard to the current debate on a follow-up UN-mission the author takes stock of the ESDP-mission. Considering the mission's problems, he makes propositions for an efficient transition of the ESDP-mission to the UN. Finally he recommends a comprehensive strategy for a European contribution to enduring freedom in the region.

\section{Übersetzungen aus dem Deutschen von Tanja Leppik-Bork und Julian Plottka.}

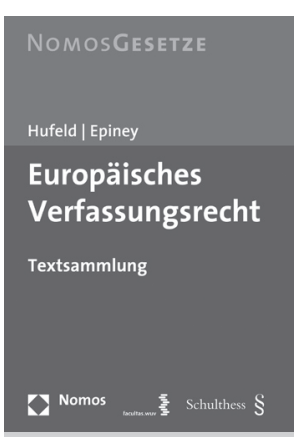

Bitte bestellen Sie im Buchhandel oder versandkostenfrei unter $\checkmark$ www.nomos-shop.de

\section{Europäisches Verfassungsrecht Textsammlung Herausgegeben von Prof. Dr. Ulrich Hufeld und Prof. Dr. Astrid Epiney} 2008, 575 S., brosch., 39,-€, ISBN 978-3-8329-3881-9

Die Textsammlung „Europäisches Verfassungsrecht“ beinhaltet die zentralen verfassungsrechtlich relevanten Texte der Europäischen Union sowie ihrer Mitgliedsländer. In einem einführenden Text wird die europarechtliche und die staatsrechtliche Perspektive der Europäischen Verfassungsgemeinschaft erläutert.

Nomos 